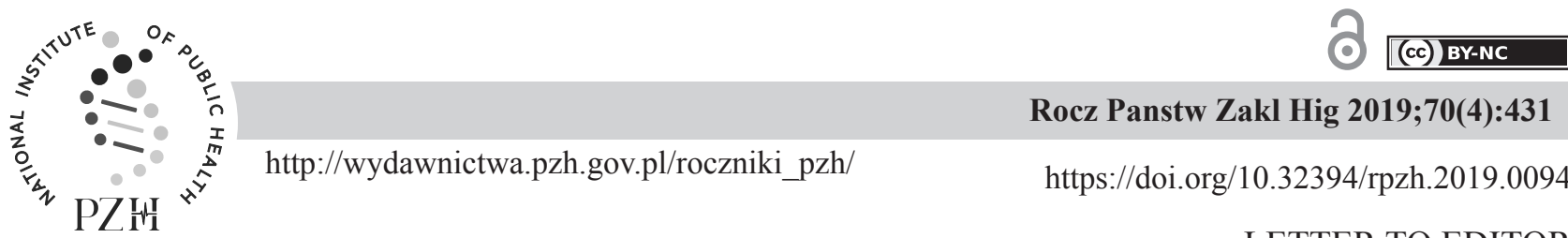

LETTER TO EDITOR

\title{
COMMENT ON PERIODIC VEGETARIANISM AND THE FIRST MENTIONS OF A PLANT DIET IN POLAND (ROCZ PANSTW ZAKL HIG 2019;70:217-223)
}

\author{
Kamil K. Hozyasz
}

Institute of Health Science, State School of Higher Education, 95/97 Sidorska Str., 21-500 Biała Podlaska, Poland

In 1880 Alfred von Seefeld (25.08.1825-12.08.1893) published in Hannover a book devoted to vegetarianism [1], which four years later was translated into Polish, with the subtitle "wegeteryjanizm" and a commentary on plant-only diet ("pożywienie wyłącznie roślinne") by Konstanty Moes-Oskragielto (6.01.1850-27.01.1910) [2]. In the late $19^{\text {th }}$ century, Moes-Oskragietto's own literary output on a plant-based diet [3,4] initiated an emotional discussion among Polish medical practitioners $[5,6]$ and, once translated into Russian, went on to have a big impact on Russian vegetarians, including Lev Tolstoy [7]. In 1883, Moes-Oskragiełlo founded a natural medicine clinic ("Leczniczy Zakład Termopatyczny") offering vegan dishes in Otwock near Warsaw [6]. In this respect, Skorek et al.'s [8] claim that the first mention of a plant diet in Polish society and its scientific literature appeared as late as 1912 must be corrected.

Moreover, in discussing the history of vegetarianism in Poland, it is worth mentioning that a large part of the former Polish-Lithuanian Commonwealth's population adhered closely to the dietary recommendations of Eastern Orthodox Christianity, which advocated so called periodic vegetarianism [9] and from which we can discern the origins of contemporary so-called fast dishes in Polish cuisine [10, 11]. It is also worth noting that Moes-Oskragietto, born in a family with Dutch roots, grew up in an area inhabited by numerous Eastern Orthodox Christians [6]. Reduced intake or complete abstinence from food of animal origin is practised by Orthodox Christians for a total of 180-200 days annually [12]. The duration of fasting periods can range from seven weeks, in the case of the Great Lent (meat, dairy products and eggs are not allowed, but fish can be consumed on Lady Day and Palm Sunday, and caviar on Lazarus Saturday) and 40 days, in the case of the Christmas fast, to a single day (e.g. Wednesdays, Fridays, the eve of the Epiphany [18 January in the Gregorian calendar], the Beheading of St John the Baptist [11 September] and the Exaltation of the Holy Cross [27 September]).

Received: 27.10 .2019

\section{REFERENCES}

1. von Seefeld A.: Altes und Neues über die vegetarianische Lebensweise. Hannover, Verlag Schmorl \& von Seefeld, 1880.

2. von Seefeld A.: Jarosz i Jarstwo (wegetaryjanizm). Przyczynki do nauki o pożywieniu wyłącznie roślinnym, jako jedynym środku wyzwolenia się od chorób fizycznych, moralnych i społecznych, słowem odrodzenia się rodzaju ludzkiego. Przełożył z niemieckiego i wstępem opatrzył K. Moes-Oskragiełto. Warszawa, Druk: Józef Unger, 1884

3. Moes-Oskragiełło K.: Przyrodzone Pokarmy Człowieka. Wpływ ich na dolę ludzką. Warszawa, Druk: Bracia Jeżyńscy, 1888.

4. Moes-Oskragiełło K. Jarstwo i Wełniarstwo w Dziejach Słowiańszczyzny. Druk: S. Niemiera, Warszawa, 1888.

5. Bednarz-Grzybek R.: Justyna Budzińska-Tylicka (18671936) - Views and ideas on nutrition. Lubelski Roczn Pedagog 2013;32: 11-24 (in Polish).

6. Smaga Ł.: Konstanty Moes-Oskragiełło - Ojciec Polskiego Jarstwa (e-book). 2017.

7. Tymieniecka-Suchanek J.: [Prolegomena to Polish studies into vegetarianism in Russia at the turn of the twentieth century]. Studia Europaea Gnesnensia 2019;19:97129 (in Polish)

8. Skorek P., Glibowski P., Banach K.: Nutrition of vegetarians in Poland - A review of research. Rocz Panstw Zakl Hig 2019;70:217-223

9. Delimaris I.A.: Potential health benefits of the periodic vegetarianism in Greek Orthodox Christian diet: A brief overview. Sci Chron 2012;17: 79-82

10. Potocki A., Lang-Mtynarska D., Wójtowicz B., Zajac J.: Changes in nutrition among the inhabitants of Southern Poland (Galicia) against a background of economic and political changes between XIX and XX century]. Hygeia Public Health 2012;47:518-524 (in Polish)

11. Mitrofanova A.: Orthodox fasting in a post secular society: The case of contemporary Russia. Religions 2018;9: 267

12. Lazarou C., Matalas A-L.: A critical review of current evidence, perspectives and research implications of diet-related traditions of the Eastern Christian Orthodox Church on dietary intakes and health consequences. Int J Food Sci Nutr 2010; 61: 739-758

The Editorial Office invites to read the above Letter to Editor and encourages our Readers for comments.

Corresponding author: Kamil K. Hozyasz, M.D., Ph.D, Institute of Health Sciences State School of Higher Education 95/97 Sidorska Str., 21-500 Biała Podlaska, Poland phone: +48 602336954, e-mail: khozyasz@gmail.com

(C) Copyright by the National Institute of Public Health - National Institute of Hygiene 